$\triangle$ CTA NEOPHILOLOGICA

UDK: 821.111(540).09Khair T.

DOI: 10.4312/an.52.1-2.59-68

\title{
An Unwilling Suspension of Misbeliefs: Acknowledging the Complexity of Reality in Night of Happiness by Tabish Khair
}

\section{Elisabetta Marino}

\section{ABSTRACT}

By focusing on Tabish Khair's latest literary endeavour, a short novel entitled Night of Happiness (2018), this paper sets out to investigate what, in the writer's opinion, is the root of most problems affecting human relationships and society as a whole: our unwillingness to embrace the unexpected complexity of reality, reassuringly misperceived through the filter of one's misconceptions.

Key-words: fundamentalisms, identity, Night of Happiness, stereotypical perceptions, Tabish Khair 
A highly-esteemed critic, an insightful journalist, a prolific author of poems, plays, and novels (shortlisted for several prestigious prizes), Tabish Khair (1966-) is also an associate professor in the Department of English of the university of Aarhus (Denmark), where he currently lives. His thriving artistic career has followed an unconventional path, thus challenging the "prerequisite requirement" of the global publishing industry that, according to Om Dwivedi, binds promising authors with a non-Western background together: their coming "from major places which share some connection with British colonialism" (10). Quite the opposite, Khair was brought up in a Muslim family in Gaya, a small town in the backward and remote state of Bihar. He spent the first thirty years of his life in India, where he earned both his BA and MA; then, for purely personal reasons, he decided to move to Copenhagen (not to London or any other Western metropolis), where he broadened his education and gained a PhD in 2000. Given the cross-cultural and religious relevance of Gaya (Buddha's place of enlightenment as well as an internationally renowned Hindu pilgrimage destination), he grew up "more as a cosmopolitan person" (Dharker 33); hence, as he observes, he "was attracted to the world and [he] was interested in difference" (33). ${ }^{1}$

Khair has been recently described by Om Dwivedi and Cristina Gàmez-Fernàndez as "a humanist" (xv), as a "socially responsible writer" (xv) who, far from merely entertaining his readers, wishes "to provoke thought and thus augment moral and ethical values in society" (xv). Moreover, the two scholars have emphasized Kahir's uncompromising rejection of literary labels - postcolonial/ diasporic/ transnational/ postmodern, to name a few - applied to his (or anybody's) output, as categorizations entail (over)simplifications and restrictions, through the adoption of theoretical lenses that fail to capture the complexity of a work of art, mirroring a multi-faceted and ever-changing reality. In his view, valuable books are those that "make you think anew" (Khair, "Non-Fiction”), by suggesting fresh perspectives, while unsettling deeply ingrained sets of beliefs and assumptions. As he further underlined in the 2011 volume of criticism he wrote with Sebastién Doubinsky, literature "is where we are confronted with the possibilities, problems and limits of language, which are finally also the problems of reality (and representation)" (Khair, Doubinsky 10). Innuendoes, gaps, silence, therefore, are equally important, since "the best writers make the most of not just what can be said but, above all, what cannot be said" (11). Accordingly, the reader

1 Besides, as he mentioned to Gautam Karmakar, he "grew up in an open and religious Muslim family, going to a Roman Catholic school, and surrounded by Hindu friends and neighbours. The idea that one has to show respect to other religions [...] was a lifestyle" (273). 
envisioned by Khair refuses to stay "on the surface of the text" (Khair, "The Death" 131): by assuming the role of a critic, s/he is an "active thinker and interpreter" (131), who explores the crevices between words and lines and, just like the protagonist of Seamus Heaney's renowned poem, digs out previously unforeseen alternatives.

In recent years, Khair has been engaged in tackling crucial contemporary issues, such as Islamic fundamentalism and xenophobia. ${ }^{2}$ As this essay sets out to elucidate, in his latest literary endeavour, a short novel entitled Night of Happiness (2018), the author encourages his readers to expose the root of most problems affecting human relationships and, therefore, society as a whole: our unwillingness to embrace the intricacies, the unexpected multiplicity of reality, reassuringly misperceived through the filter of one's biases and preconceptions, and thus commonly misinterpreted. As will be shown, religious radicalism and discrimination also stem from this core pathology.

Narrated by a high-flying entrepreneur, Anil Mehrotra, the narrative explores his increasingly perplexing connection with his right-hand man, Ahmed, regarded as a trustworthy and diligent employee until the incident that triggers the plot. Always cooperative and unpretentious, Ahmed has only ever asked for one day off a year to celebrate Shab-e-baraat, the night of happiness and salvation, a Muslim festival that "links the past to the future" (Khair, Night 15) through the commemoration of the dead. Due to pressing and unexpected business commitments, Ahmed is compelled to work with his boss even on that special occasion. As soon as the most urgent tasks are completed, however, Mehrotra decides to assuage his feelings of guilt by driving Ahmed home, where his wife is supposedly waiting for him to taste the delicious maida ka halwa she has especially prepared for the event. Invited to join them in the feast (even though the lady of the house might not show herself, since she observes strict purdah), Mehrotra is confronted with a most distressing experience: he is served a plate of non-existent halwa, which his host seems to be enjoying immensely, eating from his own empty dish. Furthermore, the conspicuous lock on the front door (signalling the absence of any occupant, before the two men walked in), coupled with the remarkable invisibility of Ahmed's spouse, suggest that she might also be a figment of his troubled mind. Concerned for the future stability of his company, in the hands of an evidently insane person, the narrator is determined to solve Ahmed's mystery by hiring a private investigator, who

2 Tabish Khair has released two "sister novels" (Karmakar 279), How to Fight Islamist Terror from the Missionary Position (2012) and Just Another Jihadi Jane (2016), and a philosophical treatise entitled The New Xenophobia (2016). In 2008, some of his essays published between 2001 and 2007 were collected by Renu Kaul Verma in a volume, entitled Muslim Modernities: Tabish Khair's Essays on Moderation and Mayhem. 
gradually uncovers the tragedies of his individual (and collective) past, first of all the ferocious murder of his beloved wife during the Gujarat riots. ${ }^{3}$

From the very choice of the genre for his novel, Tabish Khair challenges his readers to think beyond conventions and expand their horizons. Depicted by Avantika Mehta as a "literary thriller with a gripping and well-constructed plot" ("Review: Night of Happiness by Tabish Khair"), Night of Happiness actually defies any form of classification, as Mandira Nayar has also pointed out, by viewing it as "part fable, part thriller and part philosophical" ("Night of Happiness: A Serving of Distilled Wisdom from Tabish Khair"). By following the narrator of this "haunting tale" (Mokkil, "The Islamic Factor") and his line of reasoning, readers gather that appearances may be deceptive, perceptions (even self-perceptions) might prove inaccurate, and simplifications inevitably lead to misunderstandings and mistakes. Indeed, only when the end of the story is reached, can its beginning be thoroughly understood, thus casting a different light on its main characters.

The son of a diplomat and a successful manager, Anil Mehrotra belongs to a privileged class, as his $\mathrm{PhD}$ from Columbia University, his brand-new Toyota Innova (normally driven by a chauffeur), his iPhone, his golf-club membership, and the fancy party he gives and attends unmistakably testify. He introduces himself as "a man of action" (Khair, Night 42), who takes pride in "thinking logically" (42), while running his "life (and business) on clear lines" (50). ${ }^{4}$ His most used adjective is probably sensible: he leads a "sensible life" $(139,144)$, plays golf, a "sensible game" (64), and his marriage is "a sensible one" (75), surely meant to last, since no "deep existential issues" (75) are ever addressed in conversation. The charming family picture sketched by Khair - a refined and cultivated couple with two adorable, cornflakes-eating girls in immaculate school uniform, against the background of a lavishly furnished house ${ }^{5}$ - is reminiscent of many a scene of delightful domesticity taken from a 1960s Hollywood movie.

With his perfectly balanced, successful, and well-organized existence, Mehrotra seemingly epitomizes the virtues of dependability and integrity. Readers are, therefore, persuaded to accept his account of the facts as truthful, while sharing his doubts on Ahmed's mental sanity, after the unpleasant episode of the invisible

3 As Tabish Khair explains in his novel (126), the 2002 violence was instigated by the death of more than fifty Hindu pilgrims on a train that was seemingly set on fire in Godhra (Gujarat). Returning from Ayodhya (Uttar Pradesh), the Hindu pilgrims had taken part in a ceremony at the site where Babri Masjid (a large mosque) used to stand before its demolition (supposedly, the mosque had replaced a pre-existing temple of Rama and, therefore, it had been pulled down). Accused of causing what, later on, turned out to be most likely an accident, the minority Muslim population in Gujarat was persecuted and hundreds were slaughtered.

4 In Mehrotra's words, his business is "a well-oiled machine" (Khair, Night 49).

5 See, for example, p. 49. 
halwa. Yet, from the opening pages of Night of Happiness, Tabish Khair provides a variety of conflicting clues that betray the narrator's lack of judgement, his partiality, and his total unreliability, despite his impeccable façade. To begin with, Mehrotra is a confirmed liar, who often fabricates alternative versions of the facts to suit his purposes. ${ }^{6}$ Secondly, he does not seem to know his own country and its history: educated abroad, he believes Surat (where Ahmed and his wife had previously settled) is "a relatively small place" (125); in truth, it is the eighth largest city in India and one of the fastest growing in the world. Besides, when the detective mentions 2002 as a tragically pivotal year in Ahmed's life, the narrator cannot recall any particular incident connected with it, apart from the frivolous "golden jubilee of Queen Elizabeth" (124) and the outbreak of the Iraq War (which, in actual fact, began only in 2003). Hence, the detective has to remind him of the Gujarat riots and the brutal killings of Muslims committed in Surat by groups of Hindu nationalists. ${ }^{7}$ A beef-eater Hindu (another proof of his inconsistency), Mehrotra is strongly prejudiced against the Indian Muslim community. When he relates his initial acquaintance with Ahmed, during a job interview at his newly started company, he candidly admits that, being the only Muslim applicant, he was "prepared to reject him" (8) even before meeting him, for the very reason that he "had never known a Muslim intimately" (8): "one wants to work with known factors. First rule in business, first rule in life: work with known factors" (8). Behind this seemingly winning (and sensible) motto, there lurk the spectres of narrow-mindedness and bigotry. Eventually, Ahmed is selected among the other candidates for his outstanding knowledge of foreign languages, ${ }^{8}$ surely an asset for any import-export business. Nonetheless, even after years of fruitful and peaceful collaboration with him, the association between Islamic faith and the dangers of fundamentalism continues to be inextricable and unavoidable in the narrator's mind. Indeed, thus acting like Proust's madeleine, the non-existent hal$w a^{9}$ actually kindles his dormant - albeit viable - suspicions and innermost fears. Consequently, "Islamist atrocity[ies] or terrorist attack[s]" (73), "Jihad" (23), and "Islamist terror" (94) are often hinted at in Mehrotra's remarks, especially when his disturbing employee is alluded to. Besides, in his opinion, Ahmed's stay in

6 He often lies to his wife, as when he lingers at Ahmed's house, while pretending he is being delayed by the traffic (31).

7 Mehrotra openly confesses his carelessness by admitting that, later on, he had looked up the events in Gujarat on Wikipedia, "so deep down in the swamp of [his] consciousness had the tragedy sunk" (126).

8 Ahmed speaks English, Hindi, Urdu, Marathi, Gujarati, Bhojpuri, Bangla, Arabic, French, German, Thai, Tibetan, Japanese and "a smattering of Chinese" (8).

9 For Md. Sajidul Islam, "the halwa is a metaphor for Ahmed's faith" (1131) and for the "invisibilization" of the Muslim minority. 
Mumbai (a city with "a huge underworld [... and] terrorist links" [117]) constitutes the supposedly irrefutable evidence of his involvement in obscure Islamist plots. ${ }^{10}$ Lastly, his polite but insistent request to have a day off on Shab-e-baraat is depicted as an unmistakable act of intimidation and harassment: "it sent a sliver of unease through [Mehrotra] - perhaps what you would feel if a loaded gun was pointed, playfully, at you" (17).

Just like in life, however, in Night of Happiness the texture of reality is always more complex than one's perception of it. Surprisingly enough, the narrator's assumptions and dark conspiracy theories are paradoxically undermined through his own portrayal of Ahmed which, most of the times, clashes against the expected image of the disquieting Other. In truth, far from resembling a religious fanatic, a would-be schemer, or even a lunatic, Ahmed appears to be the only, truly sensible and reliable character in the story. Trust is his primary value: when his boss asks him to spy on his business partners to verify their honesty, he refuses to comply, adding one of his "Ahmedisms" (43), i.e. wise and insightful sentences that reveal his personality: "What does knowledge have to do with trust, Mehrotra sa'ab? [...] There is no need for trust if one has knowledge" (56). Besides being gentle and considerate (he looks after his ailing neighbours and usually plays the part of the mediator in every dispute ${ }^{11}$ ), Ahmed is also a frank and communicative person; he believes in the importance of establishing solid human connections to such an extent that, wherever he may be, he always leaves one window open since, in his words, "to seal a space is to shut out a soul" (25). As far as his creed is concerned, he identifies himself as "nor religious or irreligious" (21). Even though Mehrotra is inclined to perceive him as a Jihadi militant, actually Ahmed is highly critical of fellow Muslims who manipulate the verses of the Quran to serve their own agendas. His family belongs to the Tableeghi Jamait, a pacifist, non-political missionary group that places a strong emphasis "on education and living an ethical life defined by Islamic precepts" (71-72), while encouraging women to further their education and look for employment opportunities. When, on Shab-e-baraat, his mother is unpredictably denied access to the cemetery on account of her gender, Ahmed does not surrender to the new regulation, which he deems unfair; instead of entering without the elderly lady, in fact, he prefers to catch one last glimpse of his father's grave from afar, walking with her along the railway tracks behind the burial ground. Ahmed's utmost esteem and consideration for women (at odds

10 The gulf between Mehrotra and Ahmed is also widened by the social distance that separates them; given its poverty, the neighbourhood where the latter lives is perceived as hostile and intimidating by the narrator: it exudes "a mix of sadness and threat" (Khair, Night 21). It should not pass unnoticed that Ahmed is even stripped of his right to a surname, which is never disclosed in the novel.

"Violence, Ahmed had once said, is a virus; it spreads by contaminating others" (125). 
with Mehrotra's perniciously stereotypical notion of Muslim men) can also be detected in his relationship with his wife. While the narrator assumes he had married within his own community, even insinuating he had chosen one of his cousins, "as Muslims are reputed to do" (26), Ahmed falls in love with a girl with a questionable background, ${ }^{12}$ whose dark complexion, slanted eyes, and high cheekbones are obvious indicators of her mixed ancestry. As Ahmed elucidates, his spouse ignored the faith she had grown up in, nor had he ever asked her to convert and observe purdah, since her belief did not matter to him (eventually, wearing a veil had been her own decision). From their initial meeting, he had unreservedly embraced the complexity of her identity: no pressure on his part to reach a clear-cut, unambiguous definition of her self. Indeed, when he had first inquired about her, he had been given different names, corresponding to as many ethnic and religious groups: Ahmed had opted for Roshni (a Muslim name) simply because he liked the sound of it.

What leaves the narrator of Night of Happiness thoroughly baffled is the bewildering split between appearance and reality, ${ }^{13}$ as well as his own inability to definitively "slot" (122) and classify Ahmed who, in his puzzled mind, passes from being a hard-working and self-effacing employee, to being labelled a madman or a prospective criminal. ${ }^{14}$ Tabish Khair plainly shows the dangers of such a partial and short-sighted simplification when the detective hired by Mehrota exposes the gruesome details of Roshni's death in Surat. First of all, the author prompts his readers to break the clichéd connection between fundamentalism and Islam, by showing that radicalization is a multi-headed monster. The woman had been brutally abused and then burned alive by a mob of Hindutva activists, who longed to "teach 'those Muslims a lesson" (127). Despite her mild nature and her respect for her neighbours' religious confession (together with her husband, she even participated in pujas, Hindu prayer rituals), Roshni had been branded as a "Muslim"15 (or, better, she had been hastily constructed as such" ${ }^{16}$ ), and therefore regarded, by definition, as an enemy, whose death would compensate for the lives of the Godhra train victims.

12 Nobody knew who her father was, while his mother was the mistress of a married man.

13 As the narrator sadly observes, "what a relief it was when things were exactly what they seemed" (42). Before the halwa incident, in fact, reality was almost bidimensional in his view.

14 As well as viewing Ahmed as a terrorist, Mehrotra also believes he might have murdered his wife.

15 Ironically, given her looks and upbringing, Roshni was not perceived as Muslim by the Muslim community. In his narrative the author also highlights that Muslim is actually an umbrella-term, as there are many varieties of Islam (Sufism is also mentioned).

16 As Khair noticed in The New Xenophobia, "it is not the difference of the stranger that is feared when we are xenophobic; it is a certain construction and understanding of difference (which might or might not exist)" (31). 
Nevertheless, as will be shown, in his novel Khair also suggests that the divide between the One and the Other may be finally bridged, and that literature is still entrusted with a crucial social function. ${ }^{17}$ Night of Happiness might be considered as a rewriting of a famous poem by Samuel Taylor Coleridge delving into the themes of guilt and atonement: The Rime of the Ancient Mariner, which is literally quoted in an epigraph placed at the beginning of the narrative, ${ }^{18}$ while serving as the leitmotiv of the volume. Weighed down by the burden of sin (he killed the albatross), the ancient mariner detains a guest, on his way to a wedding, with his compelling and disconcerting account of his South Seas experience. At first, in Mehrotra's perception, Ahmed is assimilated to Coleridge's creation, with the "glitter in [his] eye, ${ }^{19}$ a fervour in [his] voice, a grasping of the hand" (51); in fact, just like the wedding guest crafted by the Romantic poet, the narrator is prevented from joining the party he is heading to by his employee, who forcefully invites him to share his maida ka halwa together with his story. After that evening, Mehrotra is haunted by the nightmare of a hand (Ahmed's hand, as he initially believes) detaining him by the sleeve. He himself mentions The Rime of the Ancient Mariner as the possible source of his recurring dream; yet, he continues to be disturbed by its sinister and ominous implications: Ahmed might have committed a crime he still feels guilty for, or he might be planning to perpetrate one in the future. However, as the plot unravels and the narrator starts digging underneath the surface of phenomena (not unlike the mindful reader Tabish Khair wishes for in his critical essays ${ }^{20}$ ), he begins to suspend his judgements and misbeliefs - albeit unwillingly, at first -, thus acknowledging facets of reality he had previously overlooked or consciously discarded. Consequently, as soon as the disheartening details of Ahmed's story are disclosed, the narrator realizes that, actually, the mysterious hand in his nightmare did not belong to his employee but to himself: "it was my hand - I had recognized the scar that I have carried from the time I fell down and cut myself while doing the hurdles in school" (108). Hence, as Tabish Khair seems to imply by using Coleridge's poem as a strategic and thought-provoking tool, the One and the Other may play interchangeable roles, depending on one's perspective

17 Conversely, the novel lampoons both the contemporary publishers that exploit the exotic allure of some of their authors to advertise them, and the pseudo-writers that capitalize on their ethnic background to promote their self-image and the sales of their books. A humorous, recurring figure in the text is that of "a British writer of Indian origin [who] had won a major award" (41): even though he has visited India only twice in his entire life, he is hailed by his publisher as "a son of the nation" (41) and he markets himself as such.

18 "They groan'd, they stirrd, they all uprose,/ Nor spake, nor moved their eyes; / It had been strange, even in a dream,/ To have seen those dead men rise" (3).

19 In the third line of the poem, Coleridge's mariner is identified by his "glittering eye."

20 Actually, Mehrotra even interprets the gaps and silences in the detective's account of Ahmed's past life (see, for example, pages 102 and 103). 
or point of observation. Furthermore, towards the end of the novel, the narrator is delivered a fragrant tiffin carrier containing halwa which, unlike any other person in his office, he can not only smell, but also see, and taste. The confusing episode that had triggered the whole narrative is, therefore, reproduced exactly one year later: only this time Mehrotra acts as a suspicious and delusional person. In the end, the narrator eventually questions himself and his own assumptions: "what if it was my failure to see, feel, smell, touch - a lack Ahmed could not have imagined or expected after all those years we shared?" (151). Oppressed by guilt (stemming from the newly-gained awareness of his own self-centredness and frivolity), like the ancient mariner Anil Mehrotra feels obliged to tell his story, which is also Ahmed's. ${ }^{21}$ Indeed, Night of Happiness supposedly corresponds to the manuscript he frantically writes and leaves in a drawer of the five-star hotel room he locks himself in, on Shab-e-baraat, the night of forgiveness and salvation. Meaningfully enough, even though he intends to give a title to his story, since he "likes to label and file" (153), readers already know that the title "the speetral inffinitude of small distanees" (3) has been crossed out by its author: the invisible but thick walls that separate the various components of society (castes, classes, ethnic communities, religious groups, genders) can be annihilated by shifting one's point of view and embracing the multiplicity of reality. ${ }^{22}$

As Tabish Khair stated in a 2018 interview, "for me literature is the kind of writing that demands deep attention - and repeated excavations of meaning. [...] That is the reason why literature remains the best antidote to fundamentalism religious, political or economic" (Karmakar 280). In this light, given the insights it offers as well as its challenging implications, Night of Happiness certainly deserves to be read and, most of all, taught.

\section{WORKS CITED}

Dharker, Imtiaz. "Tabish Khair in Conversation.” Wasafiri, 29.1 (2014): 33-38.

Dwivedi, Om Prakash. "Introduction." Tabish Khair: A Critical Companion. Edited by Om Prakash Dwivedi. London: Roman Books, 2013: 9-17.

Gàmez-Fernandez, Cristina, Dwivedi, Om Prakash. "Introduction.” Tabish Khair: Critical Perspectives. Edited by Cristina Gàmez-Fernandez and Om Prakash Dwivedi. Newcastle upon Tyne: Cambridge Scholars Publishing, 2014: ix-xxii. Islam, Md. Sajidul. "Rising Extremism and Invisibilization of the Muslim Minority in Tabish Khair's Novel Night of Happiness." International Journal of English Language, Literature in Humanities, 7.6 (2019): 1127-1135.

21 "I do not know if it is my story or Ahmed's, or whether, as I believed once, we even have separate stories" (153).

22 The novel even ends with the word unknowable followed by a question mark. 
Karmakar, Goutam. “'Literature Is the Best Antidote to Fundamentalism:'Tabish Khair in Conversation with Goutam Karmakar." Journal of Postcolonial Writing, 55.2 (2018): 269-81.

Khair, Tabish. "The Death of the Reader." Muslim Modernities: Tabish Khair's Essays on Moderation and Mayhem. Edited by Renu Kaul Verma. New Delhi: Vitasta Publishing, 2008: 129-46.

-. "Non-Fiction." Outlook, 27 Dec. 2010, https://www.outlookindia.com/magazine/story/non-fiction/269659. Accessed 21 Aug. 2019.

-. The New Xenophobia. New Delhi: Oxford UP, 2016.

-. Night of Happiness. New Delhi: Picador India, 2018.

Khair, Tabish, Doubinsky, Sébastien. Reading Literature Today: Two Complementary Essays and a Conversation. New Delhi: SAGE Publishing, 2011.

Mehta, Avantika. "Review: Night of Happiness by Tabish Khair." Hindustan Times, 15 Sept. 2018, https:/www.hindustantimes.com/books/review-nightof-happiness-by-tabish-khair/story-1O3P771Pp1ZOxFmVOAAbVJ.html. Accessed 22 Aug. 2019.

Mokkil, Vineetha. "The Islamic Factor.” Open, 30 May 2018, https://openthemagazine.com/lounge/books/the-islamic-factor/. Accessed 22 Aug. 2019.

Nayar, Mandira, "Night of Happiness: A Serving of Distilled Wisdom from Tabish Khair." The Week, 22 Jun. 2018, https://www.theweek.in/leisure/society/2018/06/22/night-of-happiness-serving-of-distilled-wisdom-tabish-khair. html. Accessed 22 Aug. 2019.

\section{Elisabetta Marino \\ University of Rome "Tor Vergata" marino@lettere.uniroma2.it}

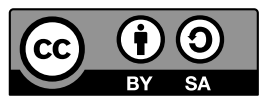

\section{Pripoznavanje kompleksnosti resničnosti v romanu Night of Happiness Tabisha Khairja}

$\mathrm{Z}$ analizo zadnjega dela Tabisha Khairja, kratkega romana Night of Happiness (2018) članek raziskuje, kaj je po pisateljevem mnenju vir večine težav, ki zadevajo človeške odnose in družbo kot celoto.

Ključne besede: fundamentalizmi, identiteta, Night of Happiness, stereotipne percepcije, Tabish Khair 